\title{
Injunction Without Damage As Illustrated By a Point in the Law of Waters
}

W

HERE decisions conflict, there is usually sufficient interest to justify an attempt to find the cause. The immediate topic, "change of use of water" is often litigated, and therefore of practical importance. Nevertheless, for our present purpose it is rather a vehicle to carry discussion of a larger principle which it illustrates, more than it is an end in itself.

In 1857 the Supreme Court of California said: "It would seem clear that a mere change in the use of waters from one mining locality to another, by the extension of the ditch, or by the construction of branches of the same ditch, would by no means affect the prior right of the party." In I860 it further ruled: "A person entitled to divert a given quantity of the water of a stream, may take the same at any point on the stream, and may change the point of diversion at pleasure, if the rights of others are not injuriously affected by the change."'

These pioneer decisions, one upholding change of place of use, and the other change of point of diversion, are the beginning from which the principle has run through the law of prior appropriation of water that an appropriator may change his use-(manner of use, place of use, purpose of use or point of diversion)-_if others are not injured by the change." It has usually passed into statute. $^{3}$ In I9Io in Colorado the point of diversion is said to be in itself a "mere incident," and in IgI4 in the same jurisdiction it is said: "We are committed to the doctrine that the point of diversion, the conduit, the place of application and the character of use may each and all be changed;"s and this was again repeated but a few months ago. ${ }^{\circ}$

The test is always added, that others must not be injured by the change. The statement in Kidd v. Laird, the original prece-

1 Maeris v. Bicknell (1857), 7 Cal. 261, 263.

2 Kidd v. Laird (1860), 15 Cal. 161, 179.

3 For example, Cal. Civ. Code, \$ 1412 .

4 Windsor Co. v. Hoffman Co. (1910), 48 Colo. 82, 109 Pac. 422.

5 Ironstone D. Co. v. Ashenfelter (1914), 57 Colo. 31, 140 Pac. 177.

${ }^{\circ}$ Arnold v. Roup (Colo. 1916), 157 Pac. 206. 
dent, is that "In all cases the effect of the change upon the rights of others is the controlling consideration." It has been universally accepted and restated. ${ }^{7}$

But the test thus given has not turned out as easy as it seemed. It has received widely variant interpretations. It is even coming to nullify the rule itself.

It invites a long-standing controversy in the law. What is such an "injury" as will prevent the change? If it means a present and immediate damage it is easy enough to apply, and is often so applied; or even if the harmful result of the change may not be immediate, it may, after delay, be sure to come; here also the test is easy enough to apply. But there is the far greater

7 The statement that the decisive test is whether the change will or will not injure others, is repeated in the authorities given in Wiel, Water Rights in the Western States, (3d ed.), Chapter 22, and the following authorities since decided:

California: Cheda v. Southern Pacific Co. (1912), 22 Cal. App. 373, 134 Pac. 717, (point of diversion); Barton v. Riverside Co. (1909), 155 Cal. 509, 101 Pac. 790, 23 L.R.A. (N.S.) 331 (point of diversion.)

Colorado: Vogel v. Minnesota Co. (1910), 47 Colo. 534, 107 Pac. 1108; New Cache etc. Co. v. Water Supply Co. (1910), 49 Colo. 111 Pac. 610, (point of diversion); Larimer Co. v. Poudre Valley Co. (1912), 23 Colo. App. 249, 129 Pac. 248, (point of diversion); Farmers Co. v. Wolff, (1913), 23 Colo. App. 570, 131 Pac. 291, (point of diversion); Montevista Co. v. Centennial Co. (1913), 24 Colo. App. 496, 135 Pac. 981, (point of diversion); Ironstone Ditch Co. v. Ashenfelter (1914), 57 Colo. 31, 140 Pac. 177, (place of use); Consolidated Co. v. Town of Evans (1915), 59 Colo. 482, 149 Pac. 834, (point of diversion); Phillips Investment Co. v. Cole (1915), 150 Pac. 331, (purpose of use); Rogers v. Nevada Canal Co. (Colo. 1915), 151 Pac. 923, (place of use); Greeley Co. v. Huppe, (Colo. 1915), 155 Pac. 386; Arnold v. Roup (Colo. 1916), 157 Pac. 206, (place of use).

Idaho: Bennett v. Nourse (1912), 22 Idaho, 249, 125 Pac. 1038, (point of diversion); Hall v. Blackman (1912), 22 Idaho 556, 126 Pac. 1047, (place of use); Joyce v. Rubin (1913), 23 Idaho, 296, 130 Pac. 793, (point of diversion); Washington Sugar Co. v. Goodrich (Idahu, 1915), 147 Pac. 1073, (point of diversion).

Montana: Featherman v. Hennessey (1911), 43 Mont. 310, $115 \mathrm{Pac}$. 983, (purpose of use); Hansen v. Iarsen (1911), 44 Mont. 39, 120 Pac. 229; Lokowich y. City of Helena (1913), 46 Mont. 575, 129 Pac. 1063, (point of diversion).

Nevada: Doherty v. Pratt (1912), 34 Nev. 343, 124 Pac. 574.

Oregon: Amalgamated Sugar Co. v. Hempe (1915), 226 Fed. 1012, (point of diversion); In re Willow Creek (1914), 74 Ore. 592, 144 Pac. 505, (place of use); In re North Powder River (1914), 74 Ore. 83, 144 Pac. 485, (place of use and point of diversion).

Washington: United States v. Union Gap Irrigation Co. (Wash. 1913), 209 Fed. 274; Mally v. Weidensteiner (Wash. 1915), 153 Pac. 342, (point of diversion).

Wyoming: Nichols v. Hufford (1913), 21 Wyo. 477, 133 Pac. 1084 (place of use) ; Groo v. Sights (Wyo. 1913), 134 Pac. 269, (point of diversion); Holt v. City of Cheyenne (Wyo. 1914), 137 Pac. 876 (point of diversion). 
field where, although the change is no immediate harm, nor sure to come, it may be impossible to say whether it will come or not. It may come and it may not come; no one can be sure. Is this risk to be forced upon the owner in such cases for the benefit of one who is changing the status quo? Is the owner "injured" by having that risk imposed upon him for the benefit of a disturber of the established order?

The test of "injury to others" opens into this wide field, into which the limitless future enters, as to what may happen. To answer it, the party wanting to change must say, "I will not harm you even in the future; harm from my change not only will not occur now, but will never occur. Damage from the change is impossible." That is a great length to go. What may or may not happen in the future only one with the gift of prophesy can prove. Just as soon as impossiblity of damage theoretically enters as a factor, it is again cast out because of the impossibility of following it up. In mathematics quantities are dealt with which grow always smaller as they are traced further, never entirely disappearing, but dwindling finally to a limit beyond which they are so infinitesimal that they must be disregarded. If "impossibility of damage" is a theoretical basis for denial of an injury, yet inability to determine it makes it finally, in the last analysis, as good as gone. Change becomes per se an injury.

Upon this basis rests the doctrine known as "injuria sine damno." It is the doctrine that protects owners against even the risk of loss from acts of another who changes the status quo. And it is working into the topic of change of water uses, turning the rule of change, if without "injury," into rule that change is per se an injury and may not be made.

Movement toward this position seems going forward in Colorado by putting upon the changer the burden of proving affirmatively that there will be no injury. There is an early ruling in California, followed in Montana, putting the burden upon the party opposing the change, ${ }^{8}$ and Colorado also was formerly strong in upholding changes. But it now demands "strict adherence to the rule that the burden of proof of showing that injury will not result is upon the person seeking judicial authority for

8 Jacob v. Lorenz (1893), 98 Cal. 332, 33 Pac. 119; Hansen v. Larsen, supra, n. 7; Lokowitch v. City of Helena, supra, n. 7. 
the change."' And it seems now so enacted in a California statute. $^{10}$

Under the form of burden of proof, or a rule of pleading and evidence, this, if logically applied, eliminates from change the greatly predominant class of cases, already mentioned, where the result of the change cannot be told in advance. Proof of the asertion of "no possible injury" is a burden which, strictly applied, will be itself impossible. It must cover the future, since title to property lasts forever ("to have and to hold unto his heirs and assigns forever"). The most that the party making the change can prove about the future is that, in view of the past experience, damage may be so remote that its possibility is beneath serious notice. But that gives him only the residue within the rule "de minimis non curat lex." It leaves to him only the extreme instances where chance of damage appears to be absolutely trivial.

Putting upon the changer the burden of disproving possible injury thus restores the familiar ground long recognized in equity jurisdiction that impossibility to measure damages is cause for equity to act by injunction to prevent interference with existing conditions. Equity, refusing to force a property owner to assume a risk, declares that "impossibility to estimate damage" is of itself sufficient cause to grant its injunction against the act complained of.

Colorado seems therefore coming, through the burden of proof, to injunction without damage; enjoining the change simply to vindicate ownership against even the chance of damage; the rule that any change is an injury per se, unless the prospect of damage is so remote and absolutely trivial as to be within the rule "de minimis non curat lex." In fact, the Supreme Court of Colorado expressly puts the burden of proof this way against the changer because he "disturbs the existing order,"11 which is the ultimate basis of the rule "injuria sine damno;" the injunction being simply to preserve existing conditions and enable the owner to say, "things shall remain as they are."

The rule that change is per se an injury is approached in another way by the holding that a certain very common type of

- Farmers etc. Co. v. Wolff, supra, n. 7. Accord, Montevista Co. v. Centennial Co., supra, n. 7; New Cache etc., Co. v. Water Supply Co., supra, n. 7. There is something of the same view in a Wyoming case, Groo v. Sights, supra, n. 7.

10 Cal. Stats. 1913, p. 1012, § 16.

$11 \mathrm{New}$ Cache etc. Co. v. Water Supply Co., supra, n. 7. 
interference is prohibited; namely, loss of return flow from the changer's ditches, flumes, or other works, or loss of return seepage to the stream from irrigated lands. Such loss so frequently, upon settled streams, attends any substantial change in point of diversion or in the locality or quality of lands irrigated or in the purpose of use (as from water power to irrigation), that little opportunity for change remains without it where the other water users in the locality are numerous. In a Colorado case it is said of an attempt to move a point of diversion up stream, that "all ditches between the two points of diversion can be and have been supplied in a large measure by return waters which there make up the body of the stream; and therefore the change in point of diversion must necessarily injure the ditches further up the stream to the full extent of the amount changed during a considerable portion of the irrigation season."12 Of the great extent of the operation of this in practice, it has been declared: "Changes in location affect return seepage, and if permitted would makes all water titles unstable." 13 That this loss of return water is a prohibited injury and prevents change is established. ${ }^{14}$

That change is per se an injury is entering also upon the line of public policy. The Court of Appeal in Colorado says that change of point of diversion has become an excuse for renewing old claims that have never been used, and encourages speculation in such claims, resulting in irreparable loss to bona fide users,

12 Farmers etc. Co. v. Wolff, supra, n. 7.

13 U. S. Geological Survey Water Supply, paper 344, page 136.

14 California: Kidd v. Laird (1860), 15 Cal. 161; Dannebrink v. Burger (1914), 23 Cal. App. 587, 138 Pac. 751, (loss of return seepage from leaking ditches and flumes); Pomona Co. v. San Antonio Co.(1908), 152 Cal. 632-633, 93 Pac. 881, (loss of return seepage from irrigated lands)'

Colorado: Larimer Co. v. Poudre Co. (1912), 23 Colo. App. 249, 129 Pac. 248, (loss of return seepage); Montevista Co. v. Centennial Co. (1913), 24 Colo. App. 496, 135 Pac. 981, (loss of return flow); Farmers etc. Co. v. Wolff (1913), 23 Colo. App. 570, 131 Pac. 291, (loss of return seepage from irrigated lands); Fort Collins Co. v. Larimer Co. (Colo. (1915), $156 \mathrm{Pac}$. 140, (loss of return seepage.)

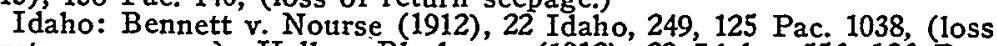
of return seepage); Hall v. Blackman (1912), 22 Idaho, 556, 126 Pac. 1047, (loss of return seepage from irrigated lands); Washington Sugar Co. v. Goodrich (Idaho, 1915), 147 Pac. 1073, (loss of return flow by change from sawmill to irrigation.)

Montana: Featherman v. Hennessey (1911), 43 Mont. 310, 115 Pac. 983, (loss of return flow by change from power to irrigation.)

Oregon: In re North Powder River (1914), 75 Ore. 83, 144 Pac. 486, (loss of return flow by change from water power to irrigation.) Washington: U. S. v. Union Gap Co. (1913), 209 Fed. 274, (loss of return flow.) 
and its effect has been vicious. ${ }^{15}$ In California the legislature has joined the current of legislation by prohibiting change of point of diversion except upon investigation and permission from State officials. ${ }^{16}$ Of change of place of use on a sale, the Supreme Court of Oregon says that any surplus over the initial use of the prior appropriator belongs to other existing users, and change by sale for use on other lands is against the tendency of law. ${ }^{17}$ And in another case the same Court says: "In the arid states the principle is gaining ground 'that the right to use the water for irrigation inheres in the land irrigated,' and is inseparable therefrom or separable only with permission of the water board or like authority."18 In Wyoming a statute was made to read, "Water rights cannot be detached from the lands, place or purpose for which they are acquired, without loss of priority."19 Of change of purpose of use, a California Statute now reads, "Water .... appropriated or acquired for one specific purpose shall not be deemed to be appropriated or acquired for any other or different purpose." ${ }^{\text {,20 }}$ This widening application, to all classes of change, of the rule that a change is of itself an injury is urged in the field as the progressive and advanced doctrine. It is said that "changes from one purpose to another without loss of priority should be prohibited as against public policy, because different amounts of water are consuned in different uses. Most changes seriously affect other rights below." 21

Complete recognition of the rule "injuria sine damno," whereby change of the status quo is an injury per se to existing owners, is. in entire possession of the class of cases involving change of structures (such as a ditch, fluine, dam, road) upon another's land. This is an injury per se that will be enjoined at the landowner's request without a showing of actual damage. Even though the easement for the structure was acquired while the land was still public, yet after the land upon which the structure lies has become private any change is per se an injury to such landowner, because

15 Farmers Co. v. Wolff (1913), 23 Colo. App. 570, 131 Pac. 291.

16 Cal. Stats. 1913, p. 1012, § 16.

${ }_{17}$ In re North Powder River (1914), 75 Ore. 83, 144 Pac. 486.

18 In re Willow R. (1914), 74 Ore. 592, 144 Pac. 505. See also Claypool v. O'Neill (1913), 65 Ore. 511, 133 Pac. 349.

${ }_{19} \mathrm{See}$ Groo v. Sights (Wyo. 1913), 134 Pac. 269, holding that this does not prohibit change of point of diversion.

${ }_{20}$ Cal. Stats. 1913, p. 1012, § 39. See also $\$ \S 11,17,20,23,33,39,41$.

21 U. S. Geological Survey Water-Supply Paper, 344, page 135. 
an owner of land has the absolute right to keep it in the condition that he got it. A strong ruling to this effect is quoted in the note, and is in accord with general authority at this time. ${ }^{22}$ Nor is there room for a contention that the change would be a benefit rather than a detriment to the landowner; he has the right to be his own judge of that or he would cease to be master of his own property. ${ }^{23}$

Exceptions must be noted.

Rights of action for change of the status quo belong to the

22 "That a change in the mode of enjoyment might have been made while the government still owned the servient tenement does not alter the case. That was because the owner of the servient tenement-the government -had accorded a license through the statute to appropriate any such rights at any time prior to the grant of patent or allowance of homestead or preemption. But, when the government granted the fee, it granted it subject not to the license, but to vested and accrued rights which had then been acquired under the license. By the grant the title to everything not then appropriated became vested in the respondents as completely as the appropriated rights had become vested in the appellant. Thereafter the jus disponendi incident to the fee was in respondents as to every right not vested in others by actual prior appropriation. The manner of diversion, the length and location of the right of way, the means of conveyance of the water over the right of way-in short, the easement-became fixed and determined by the facts as they-existed when respondents' homestead entry was allowed. No change can now be made in the character of the servitude. A pipe line cannot be substituted for a ditch and flume, nor the right of way changed or lengthened. As to these things the authorities are uniform." White Bros. v. Watson (1911), 64 Wash. 666, 117 Pac. 497, citing inter alia Wiel, Water Rights in the Western States (2d ed), pp. 285,286 , \& 179-180. See also Wiel, Water Rights (3d ed.), § 221 et seq., 499; and the following authorities since decided:

California: Brown v. Ratliff (1913), 21 Cal. App. 282, 131 Pac. 769. Colorado:Haines v. Fearnley (1914), 56 Colo. 243, 138 Pac. 541 ; Larimer Co. v. Larimer Co. (1914), Colo. App., 143 Pac. 270; Snyder v. Colorado etc. Co. (C. C. A. Colo.) 181 Fed. 62.

Idaho: Young v. Regan (1911), 20 Idaho, 275; 118 Pac. 499; King v. Chamberlain (1911), 20 Idaho, 504, 118 Pac. 1099; Marshall v. Niagara Co. (1912), 22 Idaho, 144, 125 Pac. 208; Tobey v. Bridgeford (1912), 22 Idaho, 566, 127 Pac. 178.

Kansas: Rolers v. City of Hutchinson (1910), 83 Kan. 618, 112 Pac. 129.

Nevada: Bidleman v. Short (Nev. 1915), 150 Pac. 834.

Oregon: Pringle Falls Co. v. Patterson (1913), 65 Ore. 474, 132 Pac. 527 ; Talbott v. Joseph (Ore. 1916), 155 Pac. 184.

South Dakota: Metcalf v. Nelson (1895), 8 S. Dak. 87, 65 N. W. 911; Geiger v. McMahon (1913), 31 S. Dak. 95, 139 N. W. 958.

Washington: White Bros. Co. v. Watson (1911), 64 Wash. 666, 117 Pac. 497; State v. Superior Court (1912), 70 Wash. 442, 126 Pac. 945.

Wyoming: Bucknum v. Johnson (Wyo. 1912), 127 Pac. 904; Laughlin v. Bd. of Control (Wyo. 1912), 128 Pac. 517; Groo v. Sights (Wyo. 1913), 134 Pac. 270.

${ }_{23}$ "Counsel argues with much force and persuasiveness that, inasmuch as the respondents will in no wise be injured by a change from ditch and flume to pipe line, the right to make the change should be accorded to the 
parties whose rights are infringed. Persons not in privity with an infringed owner have no standing to complain. Change of point of diversion, or manner, place or purpose of use cannot be contested by one who is not himself affected, on the plaint that others on the stream, however many, are going to suffer. That is no argument. Between strangers to the landowner, ditches on his land may be changed at will. So long as he is silent, no rival appropriator can avoid the change as being a violation of the right of the landowner. So, also, any one appropriator may change as against a rival appropriator not injured thereby, however much the change may or may not infringe upon still other appropriators or riparian owners. The party actually infringed may have the paramount right, but so long as he is silent the first appropriator has a possessory right in the changed use, which is good against the world except the paramount right, and until the paramount right is asserted. ${ }^{24}$

Another exception is that injunction against changes is given to preserve existing rights in natural streams. Flows of artificial origin are not included. The creator of the artificial flow may make changes at its source without hindrance from others to whom it has come, for such others have no right of continuance of the source, against him. In natural flows the source is by natural creation, but in waste from a ditch, or the run-off of water pumped from a mine, or the like, the source is manufactured by the ditch or pump owner. Rights against him in the source would be rights to have his "water factory" kept going.

appellant; that the taking of the additional right of way and conducting the water in a pipe line invades no substantial right of the respondents. But even if it were shown that the change would be an actual benefit to the respondents, we would have no power to compel them to accept the benefit. The question is one of property rights, not of benefits or injuries. Many authorities so hold, and we have been cited to none to the contrary. "No one has a right to compel another to have his property improved in a particular manner. It is as illegal to force him to receive a benefit as to submit to an injury." "White Bros. Co. v. Watson (1911), 64 Wash. 666, 117 Pac. 497. Accord, Allen v. San Jose Co. (1891), 92 Cal. 138, 28 Pac. 215.

24 See Wiel, Water Rights (3d ed.), Chapter 11 (Reprint); and $\S \S$ $498,499,500,625,626,627,628$; and see 1 California Law Review, 11; 2 id. 25.

"As to the question of a change in the purpose of the diversion to a different beneficial use from that of the original appropriation, appellant, not having an interest in the water by virtue of an appropriation, is in no position to complain." Campbell v. Goldfield W. Co. (1913), 36 Nev. 458, 136 Pac. 976. 
They can be had only by contract from him or the like; not by simply receiving his waste. This statement may be somewhat too broad to be exact, but it is near enough for present purposes. Any change by him of his ditch or pump, changing or stopping the source of the manufactured flow, is no cause of action. Damage or no damage does not enter here. There is no right invaded by the change in the first place; certainly not where the change is made in good faith for some purpose of the maker, without malice or mere ill-will to the persons deprived thereby. ${ }^{25}$ This exception applies, however, only to changes at the source. It also only applies to permit changes by the producer of the artificial flow. The law is that among all the rest of the world except the producer, the flow follows the usual law of water-courses, and it is immaterial between them how that flow came to be. ${ }^{25 a}$ Strangers to the producer are not concerned with his rights when they are not privy to him, and he is not setting them up himself.

The rule that change can be made "if no injury to others" was begun on common law authority. In the original precedent, cited at the beginning, for change of point of diversion, the court quoted common law decisions and texts and drew its conclusion from them. ${ }^{26}$ But when it comes to defining "injury" there is in all parts of the law this twilight zone between "damage" and "injury" that causes different views. ${ }^{27}$ An illustration elsewhere is where riparian owners seek injunctions against change of conditions by nonriparian owners. Some rulings say such change will not be stopped unless it is shown to be "injurious;" others (and the weight of authority) hold such change to be an injury "per se;" and the debate continues unsettled still. ${ }^{28}$ In the common law of easements the question has arisen how far the dominant owner can change the use of the easement. Here the ruling against the change seems to be accepted with less dispute. ${ }^{29}$

It seems worth recalling that in 1856 and 1860 , when the

25 See Wiel, Water Rights, (3d. ed.), §§ 53-62; 29 Harvard Law Review 137.

$25 a$ See the paper of the present writer in 29 Harvard Law Review, 137.

${ }^{26}$ Kidd v. Laird (1860), 15 Cal. 161, 181.

27 See 1 C. J. 964 ; Wiel, Water Rights, (3d ed.), \$ 642.

28 Wiel, Water Rights, (3d ed.), Ch. 35; 2 California Law Review, 340.

2914 Cyc. 1206, 1211. "Plaintiff established a prescriptive right to the use of the water for stock purposes, and it is so found, but there is no evidence and no finding that he acquired any such right to use the water for household or domestic purposes or for irrigation." (Held fatal). 
original rulings permitting changes were made, and during the period up to the end of the eighties when they were spread through the western water law, the locality was a wide expanse of public domain, where changes were mainly upon public land. The "injury," if any, was predominantly to the United States, who raised no objection. Since then settlement has occupied much of the region around water supplies. Land and rights in water have become private property. The rule that there must be no injury to them has become more prominent than the rule of change. Those who may be injured have increased and multiplied and now assert their rights, and along with this has come a stricter view of what constitutes an "injury."30

Whatever the reason, a glittering generality that was very easy of statement and seemed simplicity itself, seems to be turning against itself in its application today.

Samuel C. Wiel.

San Francisco, California.

Gurnsey v. Antelope etc. Co. (1907), 6 Cal. App. 393. A prescriptive right for watering stock cannot be changed to irrigation, Duckworth $\mathrm{v}$. Watsonville Co. (1907), $150 \mathrm{Cal}$. 520, 89 Pac. 338. A right of way to carry water to certain lands cannot be changed to carry it to other lands, Logan v. Guichard (1911), 159 Cal. 592, 114 Pac. 989. Easement granted for "supply pipes" of a water system cannot be changed to use as distributing pipes; that is, pipes for conveying water from one reservoir to another cannot be used for conveying water from the reservoir to consumers, Gray v. Cambridge (1905), 189 Mass. 414, 76 N. E. 195. One cannot substitute an iron pipe in place of a flume or trough, against the opposition of the owner of the land upon which it lies, Lewis v. Meredith (1913), 1 Ch. $571,580$.

30 See in Re North Powder River (1914), 75 Ore. 83, 144 Pac. 486. 